Article

\title{
Evaluating the Investment Climate for China's Cross-Border E-Commerce: The Application of Back Propagation Neural Network
}

\author{
Yi Lei and Xiaodong Qiu * \\ School of Economics and Management, Business Administration, Beijing Jiaotong University, \\ Beijing 100000, China; 18113082@bjtu.edu.cn \\ * Correspondence: xdqiu@bjtu.edu.cn
}

Received: 19 October 2020; Accepted: 10 November 2020; Published: 12 November 2020

\begin{abstract}
China's cross-border e-commerce will usher in a new golden age of development. Based on seven countries which include the Russian Federation, Mongolia, Ukraine, Kazakhstan, Tajikistan, Kyrgyzstan and Belarus along the "Belt and Road", an evaluation system for cross-border e-commerce investment climate indicators is established in this study. This research applied the entropy method twice to evaluate the investment climate of seven countries based on 5 years panel data comprehensively and these countries are then classified into politics-oriented and industry-oriented countries, and then the weight of indicators for each category is analyzed. In addition, cross-border e-commerce investors are proposed to prioritize industry-oriented countries. Back propagation neural network algorithm is used to map the existing data and optimize the evaluation index system in combination with the genetic algorithm. This research denotes the effort to find out the index evaluation combination corresponding to the best overall score, make the established evaluation index system applicable to other countries, and provide reference for cross-border e-commerce investors when evaluating the investment climate in each country. This study provides the important practical implications in the sustainable development of China's cross-border e-commerce environment.
\end{abstract}

Keywords: "Belt and Road" countries; e-commerce; investment climate evaluation; entropy method; neural network

\section{Introduction}

China has formulated a new Silk-Road strategy, referred to the "One Belt, One Road" initiative, implemented under the Xi Jinping administration. The move aimed at stimulating growth and improving ties with nations along its geographic periphery [1]. Since the promulgation of the document "Vision and Action on Jointly Building Silk Road Economic Belt and 21st Century Maritime Silk Road" in March 2015, China has been stepping up its efforts to reinforce global open cooperation and actively promote the construction of a partnership of interoperability among countries along the route. To achieve common development and prosperity, China is pushing for innovative approaches in trade, building a cooperative and win-win economic cooperation framework, establishing a comprehensive, multi-level, and complex Unicom-based trading network, and promoting deep-level regional cooperation. Huang [2] pointed out that the "One Belt, One Road" initiative was a new form of international economic cooperation between China and its new partners. It was important to promote economic growth, and it was a significant contribution to the adjustment of the international economic system. Michael et al. [3] argued that the initiative was a sustainable development model that realized international economic, political and cultural development through diversified communication and exchange under the principle of peaceful coexistence among countries. Kamel et al. [4], Herrero et al. [5] 
and Huang et al. [6] analyzed the economic and trade impact of the "One Belt, One Road" initiative for the Middle East, Europe, Africa and Central Asia. Most scholars believe that the Belt and Road Initiative will create a mutually beneficial and interconnected platform for cooperation, bringing tremendous economic development opportunities for China and the countries along the routes.

E-commerce, as an efficient business model, has been advancing rapidly in recent years. Especially this year, under the impact of the global epidemic, e-commerce has played an important role in resisting the impact of the epidemic, boosting consumption recovery and driving global economic recovery due to its advantages of being able to break through temporal and spatial limitations, reducing intermediate links and resolving information asymmetry between supply and demand. As a country with massive scale in e-commerce, China boasts a mature logistics system, a gathered manufacturing industry chain, an efficient operation mode, a specialized platform, and a relatively complete business ecosystem, which gives the country a head start in areas like logistics, manpower, payment, etc. In 2019, the scale of e-commerce transactions in China was 34.81 trillion yuan [7], which has taken the top spot in the global e-commerce market for many years. As Yin et al. mentioned, as the basis of trade globalization, e-business carries very important strategic meanings. It not only breaks the boundaries between countries and facilitates international trade, but also brings about changes to the companies and consumers, respectively [8]. In June 2015, the State Council promulgated the "Guiding Opinions on Promoting the Healthy and Rapid Development of Cross-border e-commerce" to support the development of cross-border e-commerce in finance, services, organizations and other aspects and to encourage domestic enterprises to make better use of e-commerce to conduct foreign trade. It can actively promote the development of open economy and promote the healthy and rapid development of cross-border e-commerce in China. According to statistics [9,10], as of July 2019, the Chinese government has signed 197 intergovernmental cooperation agreements with 137 countries and 30 international organizations. In 2019, China's cross-border e-commerce retail import and export volume reached 186.21 billion yuan, five times that of 2015, with an average annual growth rate of $49.5 \%$, and over 6000 new cross-border e-commerce enterprises. It is evident that the Chinese market has become more competitive and global demand for Chinese products continues to expand. It will be an inevitable trend in the future to give full rein to cross-border e-commerce and establish a complete ecosystem, which will make cross-border e-commerce more sustainable. It is foreseeable that China's cross-border e-commerce will usher in a new golden age of development.

How to better develop cross-border e-commerce against the backdrop of the "Belt and Road Initiative"? According to the location theory [11], it is of great significance to select the suitable countries and make an objective and reasonable assessment of cross-border e-commerce investment climate based on China's national conditions. In terms of industrial sector, in 2018, the total exports of the seven types of labor-intensive products, namely, textile, clothing, footwear, luggage, toys, furniture, plastic goods, reached 3.12 trillion yuan, accounting for 19.0\% of China's total exports issued by the Ministry of Commerce of China [12]. China is a big manufacturing country, and its labor-intensive products are the staple goods on the shelf in e-commerce. Therefore, tapping into China's abundant labor and exporting its labor-intensive products is a more reasonable industry choice for cross-border e-commerce. In terms of countries, important considerations are whether it is suitable for e-commerce investment, national demand and infrastructure convenience are important considerations. In northern countries along "The Belt and Road Initiative", the labor-intensive industries are typical of raw material shortage, high cost and outdated technology. They mainly rely on foreign imports. Therefore, country selection can be made according to the proportion of secondary industries in each country. The smaller the proportion of secondary industry, the greater the demand. In terms of infrastructure, the opening of the China-Europe Railway Express has brought down the cost for cross-border e-commerce and opened up the national market. Since 2014, the China-Europe train has operated a total number of 14,691 [13] with its main stops in hinterland countries being Kazakhstan, Russia, Belarus, Poland, Mongolia, Kyrgyzstan, Tajikistan and Ukraine whose proportions of secondary industry are as shown in Table 1. Among them, Russia, Kazakhstan, Mongolia and Belarus are the pivotal countries in the 
"three passages" and "five ports" of the Central European class. Kyrgyzstan, Tajikistan and Ukraine have their regular trains and the upcoming railway project. Therefore, considering the demand of the secondary industry, the distance and timeliness, this paper chose seven "the Belt and Road Initiative" land countries including Russian Federation, Mongolia, Ukraine, Kazakhstan, Tajikistan, Kyrgyzstan and Belarus as its research object, to study the cross-border e-commerce investment climate.

Table 1. Proportion of the secondary industry of the main China-Europe Railway Express countries along "the Belt and Road".

\begin{tabular}{cccccccccc}
\hline Country & Belarus & Slovakia & Poland & Mongolia & Russia & Kazakhstan & Kyrgyzstan & Tajikistan & Ukraine \\
\hline Proportion & 37.70 & 34.82 & 34.12 & 33.82 & 32.79 & 32.53 & 28.43 & 28.00 & 25.65 \\
\hline \multicolumn{8}{c}{ Data source: World Bank. }
\end{tabular}

Artificial neural network, a feed-forward network algorithm simulating the animal nervous system, has been advancing rapidly in recent years. Many scholars at home and abroad have researched various aspects of e-commerce combined with the neural network, which achieve good results. Some scholars [14-16] applied neural networks to e-commerce, which included merchandise, customs classification and advertisement. Some scholars [17-20] used neural networks to study consumer purchasing behavior. Others [21-25] applied it to other fields where engineering and humanities were included. Neural networks have been shown to be effective in mapping nonlinear input and output parameters.

Currently, under the trend of trade globalization and booming e-commerce, there are numerous investable countries. In order to help cross-border e-commerce enterprises make effective investments and improve the quality and efficiency of trade cooperation between countries, an evaluation system for cross-border e-commerce investment climate indicators is established in this paper. The entropy method is used to comprehensively evaluate the investment climate of the seven countries. The neural network method is used to map the existing data, and optimize the evaluation index system in combination with the genetic algorithm, which can make the established evaluation index system applicable to other countries, and provide reference for cross-border e-commerce investors in time of evaluating the investment climate in each country. Previously, few scholars have used neural network to study the cross-border e-commerce investment climate, and no one has used genetic algorithms so as to verify the objectivity of the established evaluation index system and optimize the combination of indicators to make it more applicable.

\section{Literature Review}

Since China proposed the Belt and Road Initiative in 2013, it has attracted widespread attention from the international community. The initiative has sparked widespread discussions and studies on political systems, commerce, geopolitical factors, etc. Wang [26] examined the existing mechanisms for resolving disputes in "Belt and Road Initiative", pointing out shortcomings and rooms for improvement. Wu et al. [27] discussed the impact of national distance on international trade under the "Belt and Road Initiative". Some scholars [28-30] studied the Belt and Road Initiative in terms of geopolitics, geopolitics and transportation. Julien [31] explored China's investment policy and strategy of three tracks-bilateral agreements, regional agreements and global initiatives. Liu et al. [32] discussed the construction of the Belt and Road Initiative from neo-liberal to inclusive globalization. Ailan et al. [33] analyzed the role of cultural and institutional distance in international trade.

From the above, it can be seen that the Belt and Road Initiative proposed by China is a complex but meaningful project that varies greatly among countries and industries. As an institutionally driven business-oriented behavior, it is important to study the investment environment for Chinese companies in different countries under the initiative.

In 1968, Litvak and Banting proposed the concept of "investment climate" for the first time and constructed an evaluation index system based on seven aspects, such as political stability and legal obstacles, which raised the study of investment climate to a theoretical level [34]. Since then, 
the evaluation index system of investment climate has been researched extensively at home and abroad. Yang [35] evaluated the importance of investment climate factors, namely, political, infrastructure, cost, and market factors, for firms' intention to invest in international logistics zones. Maung et al. [36] studied how a country's investment climate affects cross-border merger and acquisition premiums. Ershova [37] establishes an evaluation index system consisting of market demand, infrastructure and legal environment. He analyzes the investment climate in Russia and determines the factors that attract foreign investment to Russia and the factors that hinder foreign investment in Russia. Beleska et al. [38] studied the impact of the competitive advantage of the emerging economy, Thailand, and establishes eight competition indicators, including demand conditions, business environment, government and political environment, etc. It is proposed that a country's competitive advantage is also an important factor in evaluating investment climate. Bevan et al. [39] studied the determinants of foreign direct investment from Western countries, mainly in the European Union, found the most important influences to be unit labor costs, gravity factors, market size, and proximity. Jurgita et al. [40] assessed country investment attractiveness through the economic subjects' competences and environment empowering them to attract and maintain investments in the country. These are studies of the factors influencing the investment climate.

Some scholars [41-43] focused on the investment climate in a particular industry, such as new energy, natural gas and mining. In addition, Deng et al. [44] presented a practical for evaluating investment climate from the viewpoint of a host region or country. Nam et al. [45] introduced and validated a scale for measuring entrepreneurial investment climate, consisting of four factors: Societal stability, Labor and Regulations, Quality of Infrastructure, and Ease of Finance. Varoudakis [46] revisited the link between firm-level investment climate and productive performance.

A summary of the references shows that the investment climate has been studied from different perspectives, from the point of view of influencing factors, evaluation methods, enterprise level and generally through the establishment of evaluation index systems. However, so far, a fixed and unified index system is absent, and there is very limited research on the evaluation index system based on the cross-border e-commerce investment climate. Given the fact that e-commerce has its unique demand, namely, a fairly high requirement for industry environment like internet penetration rate and logistics environment, the traditional indicator system, therefore, is no longer applicable, and it is urgent to establish a set of investment evaluation index system based on cross-border e-commerce.

\section{Materials and Methods}

\subsection{Materials}

On the basis of data availability and quantifiability, and the special needs of e-commerce for indicators, based on an integrative study of evaluation index system proposed by scholars at home and abroad, an evaluation system including four first-level indicators namely, economic environment, political environment, legal environment and industrial environment is established in this paper, which contains eight secondary indicators, 17 third-level indicators. This meets the specific needs of cross-border e-commerce. All data in this paper are invariable from official channels including the World Bank database, official report from "Worldwide Governance Indicators", Census Bureau in each country, the website of "the Belt and Road Initiative", etc. The detailed indicator system is shown below in Table 2.

The economic environment has a direct impact on cross-border e-commerce investment, and its situation directly affects investment returns. A stable political environment plays an essential role in safeguarding investment, which is sometimes disrupted by the political environment especially in turbulent countries. The sound legal environment can keep each link in the chain well-oiled through regulation, restriction and maintenance. The industry environment, as a prerequisite for investment, has an immediate influence on the efficiency and development of e-commerce investors. 
Table 2. Investment environment evaluation index system for cross-border e-commerce investment in seven countries.

\begin{tabular}{|c|c|c|}
\hline Primary Indicator & Secondary Indicator & Three-Level Indicator \\
\hline \multirow{3}{*}{ Economic environment } & Economic strength & $\begin{array}{l}\text { Total GDP } X_{1} \\
\text { GDP growth rate } X_{2} \\
\text { Per capita GDP } X_{3}\end{array}$ \\
\hline & Economic stability & Inflation (measured by consumer price index) $\mathrm{X}_{4}$ \\
\hline & Economic openness & $\begin{array}{c}\text { Foreign direct investment } X_{5} \\
\text { Dependence on foreign trade } X_{6}\end{array}$ \\
\hline \multirow[t]{2}{*}{ Political Environment } & Government execution & $\begin{array}{c}\text { Government accountability } X_{7} \\
\text { Government efficiency } X_{8} \\
\text { Supervision quality } X_{9}\end{array}$ \\
\hline & Political stability & Political stability, absence of violence $X_{10}$ \\
\hline Legal environment & Legal factors & $\begin{array}{l}\text { Law-ruled environment } X_{11} \\
\text { Legal power index } X_{12}\end{array}$ \\
\hline \multirow[t]{2}{*}{ Industry environment } & Telecommunication condition & $\begin{array}{c}\text { Mobile cellular subscriptions per } 100 \text { people } \mathrm{X}_{13} \\
\text { Number of secure internet servers } \mathrm{X}_{14} \\
\text { Internet penetration rate } \mathrm{X}_{15}\end{array}$ \\
\hline & Logistics conditions & $\begin{array}{l}\text { Railway (total kilometers) } \mathrm{X}_{16} \\
\text { Airline passenger volume } \mathrm{X}_{17}\end{array}$ \\
\hline
\end{tabular}

\subsection{Methods}

\subsubsection{Entropy Method}

Entropy method is an objective weighting method, which can calculate the weight of each indicator and provide a basis for comprehensive evaluation of multi-indicators. The advantage of the method is that it can avoid the deviation which is caused by human factors, and it has high credibility and accuracy. In this paper, the entropy method is used to evaluate the weight of each indicator and it is on this basis that seven countries are given a comprehensive assessment. According to the scores, the seven countries are classified, the investment climate of different countries are discussed, and the index weight analysis is carried out for each category of countries by the second entropy method. In order to minimize errors, the five-year data from 2013 to 2017 are selected for analysis.

(1) Data standardization

Standardize data with Z-SCORE:

$$
x_{i j}^{*}=\frac{x_{i j}-x_{i}}{S_{i}}
$$

where:

$x_{i j}^{*}$-Standardized value

$x_{i j}$-Raw data of the indicator $j$ sample $i$

$x_{i}$-The arithmetic means of the $j$ th indicator data

$S_{i}$-Standard deviation of the $j$ th indicator data

The above-mentioned "samples" denote countries, and the word "indicator" refers to the three-level evaluation index of the e-commerce investment climate. Given the negative data that come as a result of standardization, according to the scholar's research on improving the entropy weight method [47] and other scholars' handling of the problem [48,49], the data can be translated to avoid meaningless calculation, and the translation value is the absolute value of $\min \left(x_{i j}^{*}\right)$.

(2) The ith sample under the $j$ th indicator accounts for the proportion of the indicator

$$
P_{i j}=\frac{x_{i j}}{\sum_{i=1}^{n} x_{i j}}
$$


where: $n$-Number of samples

(3) Entropy of the $j$ th indicator

$$
e_{j}=-k \sum_{i=1}^{n} P_{i j} \operatorname{Ln}\left(P_{i j}\right)
$$

where: $k=\frac{1}{\operatorname{Ln}(n)}$

(4) Information entropy redundancy

$$
d_{j}=1-e_{j}
$$

(5) Indicator weight

$$
w_{j}=\frac{d_{j}}{\sum_{j=1}^{m} d_{j}}
$$

where: $m$-Number of third-level indicators

(6) Comprehensive scores of countries

$$
S_{i}=\sum_{j=1}^{m} w_{i} \cdot P_{i j}
$$

\subsubsection{Back Propagation Neural Network and Genetic Algorithm}

The components of a back propagation (hereafter BP) neural network consists of input layer neuron, output layer neuron, and hide layer neuron, which are interconnected through weights. Figure 1 illustrates the structure diagram of BP neural network model. The input parameters are 17 three-level indicators of the seven-country cross-border e-commerce investment climate assessment system, which are assigned to $X_{1}-X_{17}$. The output layer is the corresponding total score of each country. The Sigmoid function is selected as the activation function, the tansig function is used as the hide layer transfer function, and the purelin function is selected as the node transfer function in the output layer.

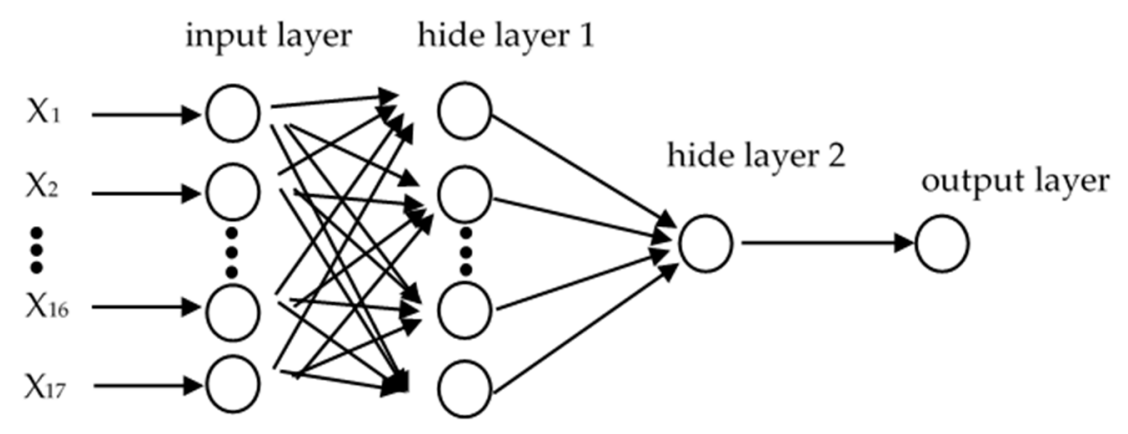

Figure 1. Structure diagram of back propagation (BP) neural network model.

Calculate the number of hide layer nodes $l$ :

$$
l=\sqrt{(n+m)}+\mathrm{a}
$$

where:

$m$-the number of nodes in the output layer

$n$-the number of nodes in the input layer

$a$-adjustment constant of $1-10$

Equation (7) is the empirical formula for the hide layer nodes of the BP neural network. " $n$ " is the number of nodes in the input layer which represents the number of indicator factors in the research. " $m$ " is the number of nodes in the output layer which means the score of investment climate. That is, $n=17, m=1$. " $a$ " is specified as an adjustment constant between 1-10. Therefore, the value of $l$ ranges 
from 5 to 15. Through the training of different node sample models, an LM optimization algorithm with fast convergence and high accuracy is used to compare the number of different hide layer nodes, and the one with the smallest error value is selected as the number of hide layer nodes.

Based on Darwin's theory of biological evolution, Genetic Algorithm is intended to seek the optimal solution by processing data through natural selection, inheritance and evolution, an approach that simulates the biological evolution in nature and is featured by the survival of the fittest. In this paper, the three-level evaluation index is used as a design variable, and the established BP neural network model is used to find the optimal solution of the fitting results of non-linear data by further expanding the parameter range.

For the evaluation indicators of cross-border e-commerce investment climate, we determine the scope of optimization parameters from the perspective of practicability and feasibility. For the percentage index, the range is from 0 to 100, and for the numerical index, the range is between 1.5 times the maximum value and 0.5 times the minimum value. The 50 individuals randomly generated by 17 design variables are used as the initial population, and are substituted into the BP neural network model. The network output is used as the target value, and is fitted to the fitness function. By choosing individuals with high fitness through selection and crossover, we iterate, evolve, and optimize mutation processes that randomly change individual genes.

\section{Results}

\subsection{Results of Entropy Method}

The analysis and calculation of entropy method can generate the weight of each indicator and the comprehensive score of each country which are shown below in Table 3.

Table 3. Comprehensive rating and ranking of cross-border e-commerce investment climate of seven countries from 2013 to 2017.

\begin{tabular}{cccccccccccc}
\hline Time & \multicolumn{2}{c}{ 2017 } & \multicolumn{2}{c}{$\mathbf{2 0 1 6}$} & \multicolumn{2}{c}{ 2015 } & \multicolumn{2}{c}{ 2014 } & \multicolumn{2}{c}{$\mathbf{2 0 1 3}$} & Avg \\
\hline Country & Score & Rank & Score & Rank & Score & Rank & Score & Rank & Score & Rank & Score \\
\hline Belarus & 0.133 & 5 & 0.133 & 5 & 0.129 & 6 & 0.136 & 5 & 0.124 & 6 & 0.131 \\
Kazakhstan & 0.163 & 2 & 0.155 & 4 & 0.166 & 2 & 0.158 & 3 & 0.152 & 3 & 0.159 \\
Kyrgyzstan & 0.123 & 6 & 0.128 & 6 & 0.129 & 5 & 0.128 & 6 & 0.142 & 4 & 0.130 \\
Mongolia & 0.161 & 3 & 0.159 & 3 & 0.151 & 3 & 0.164 & 2 & 0.172 & 2 & 0.162 \\
Russia & 0.189 & 1 & 0.174 & 1 & 0.197 & 1 & 0.188 & 1 & 0.202 & 1 & 0.190 \\
Tajikistan & 0.078 & 7 & 0.087 & 7 & 0.086 & 7 & 0.089 & 7 & 0.070 & 7 & 0.082 \\
Ukraine & 0.154 & 4 & 0.163 & 2 & 0.142 & 4 & 0.137 & 4 & 0.137 & 5 & 0.147 \\
\hline
\end{tabular}

\subsection{Results of Optimization}

We set up a neural network model, train the data with the trainlm function, set the expected error to $10^{-3}$, and the learning rate to 0.01 . The five-year data of the seven countries total 35 groups with 20 groups of them are selected as training samples, and the rest test samples. Train the network with different numbers of hide layer nodes. When $l=11$, the minimum value of MSE is $0.1883 \times 10^{-3}$. It can be determined that the number of hide layer nodes is 11 , and a 17-11-1-1 neural network prediction model is established. The model has the smallest average error of $0.202 \%$, which illustrates the effectiveness of the BP neural network for the evaluation of cross-border e-commerce investment climates in various countries. The predicted output and error of BP neural network is shown in Figure 2.

Set the genetic algorithm parameters, evolution algebra MAXGEN $=100$, cross probability $\mathrm{Pc}=0.4$, mutation probability $\mathrm{Pm}=0.2$. Considering the high degree of differences in national economic and political structures, as well as the variation in the magnitude of each indicator, 10 sets of parameter combinations with a comprehensive score of more than 0.29 are selected as the best parameter 
combinations of the cross-border e-commerce investment climate evaluation model by optimizing the specified domain of BP neural network with genetic algorithm, as shown in Table 4.

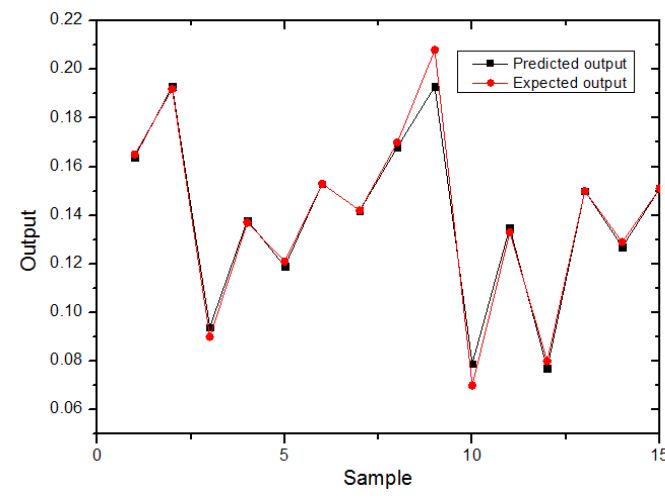

(a)

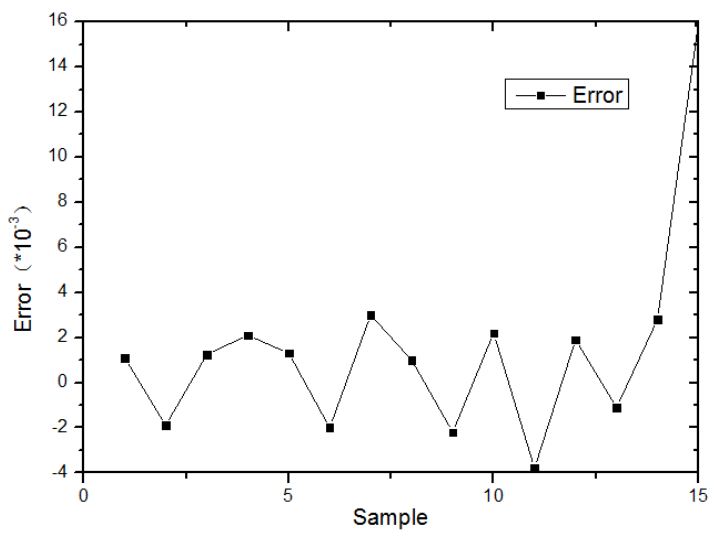

(b)

Figure 2. (a) The predicted output; (b) The error (Source: own work).

Table 4. Optimal indicator combinations.

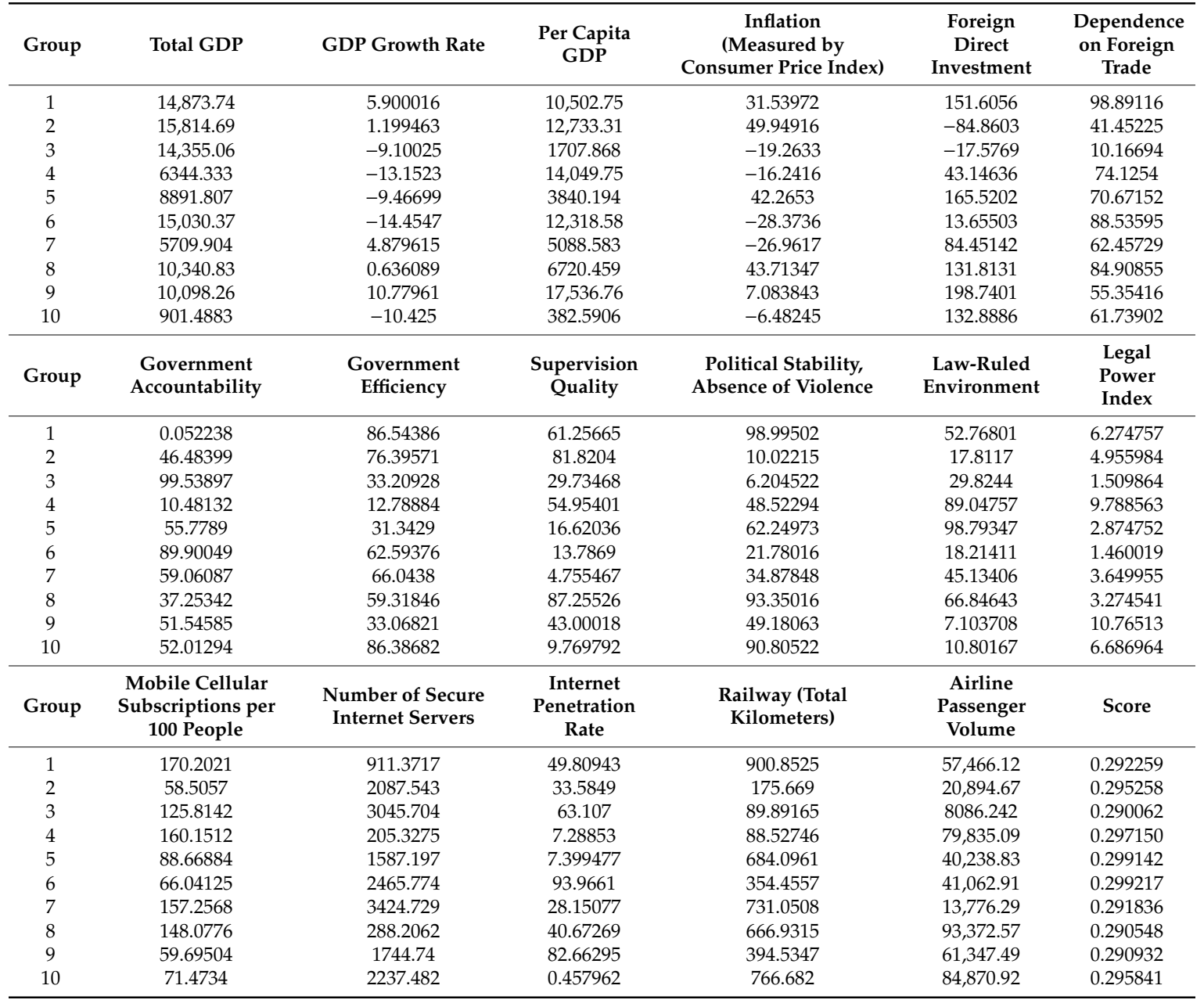

\section{Discussion}

According to the results of entropy method (Table 3), Russia tops the seven countries in e-commerce investment climate with the highest score for five consecutive years. Mongolia and Kazakhstan are 
second to Russia with a stable five-year comprehensive score of the two countries. Ukraine, Belarus and Kyrgyzstan rank from 4th to 6th, respectively. Tajikistan remains at the bottom over the five-year period. The e-commerce investment climate varies slightly from country to country, but the integration is obvious. According to the 5-year score data, except for Tajikistan which scores the lowest, the average scores of other countries are within the range of 0.13-0.20. Belarus has almost the same scores with Kyrgyzstan.

To further analyze the cross-border e-commerce investment climate, and to clarify the relationship between each indicator weight and different country types, the seven countries are divided into three categories according to the national e-commerce investment climate comprehensive score. The boundary line is set at 0.1 and 0.15 . Those scoring above 0.15 are identified as first-category countries and they include Russia, Mongolia, and Kazakhstan. They are countries with the most desirable e-commerce investment climate. The second-category countries include Belarus, Kyrgyzstan, and Ukraine, whose score is in the range of 0.1 and 0.15 . The third-category country scores 0.1 or less, namely, Tajikistan, whose e-commerce investment climate is the least well-suited for investment. The country, therefore, is not considered in subsequent analysis.

The first and second category countries are re-analyzed for their index weight of each index by using the second entropy method. The results are shown in Tables 5 and 6. Seen from these two tables, the economic environment is the most important factor in the evaluation of cross-border e-commerce investments with the scores of the surveys accounting for more than $30 \%$ of the total. The legal environment is the weakest, and the political environment and the industrial environment fall in between. Further analysis reveals that both types of countries have the following commonalities. In the comprehensive evaluation, the economic strength has the largest proportion in economic indicators, the economic openness is second, and the economic stability is the weakest. Among the political environmental factors, government executive power has the highest impact, and political stability has a weaker impact. In both types of countries, the legal environment has the same degree of influence, and is an important influencing factor in both types of countries. As for the industrial environmental indicators, the communication conditions have a greater degree of influence, and the logistics conditions are second. By analyzing the secondary evaluation indicators in both types of countries, it can be concluded that the main indicators affecting the e-commerce investment climate evaluation are economic strength, government execution, legal factors and communication conditions (Screening with factors greater than 10\%).

Table 5. Weights of indicators of the first-category countries.

\begin{tabular}{|c|c|c|c|c|c|c|}
\hline Indicator Level & Primary & & Secondary & & Primary & Secondary \\
\hline Indicator & Econ Env & Econ Strength & Econ Stability & $\begin{array}{c}\text { Econ } \\
\text { Openness }\end{array}$ & Legal Env & Legal Factors \\
\hline 2013 & 34.6 & 19.3 & 5.1 & 10.3 & 11.8 & 11.8 \\
\hline 2014 & 32.4 & 18.3 & 4.8 & 9.4 & 11.2 & 11.2 \\
\hline 2015 & 33.8 & 19.6 & 4.6 & 9.6 & 12.9 & 12.9 \\
\hline 2016 & 34.5 & 19.6 & 5.5 & 9.4 & 11.3 & 11.3 \\
\hline 2017 & 32.3 & 18.4 & 4.6 & 9.4 & 15.5 & 15.5 \\
\hline Indicator Level & Primary & \multicolumn{2}{|c|}{ Secondary } & Primary & \multicolumn{2}{|c|}{ Secondary } \\
\hline Indicator & $\begin{array}{l}\text { Political } \\
\text { Env }\end{array}$ & $\begin{array}{c}\text { Gov } \\
\text { Execution }\end{array}$ & $\begin{array}{l}\text { Political } \\
\text { Stability }\end{array}$ & Industry Env & $\begin{array}{l}\text { Comm } \\
\text { Cond. }\end{array}$ & $\begin{array}{l}\text { Logistics } \\
\text { Cond. }\end{array}$ \\
\hline 2013 & 21.8 & 16.4 & 5.4 & 31.8 & 21.8 & 10.0 \\
\hline 2014 & 26.0 & 19.8 & 6.3 & 30.3 & 21.0 & 9.3 \\
\hline 2015 & 23.6 & 17.4 & 6.2 & 29.7 & 20.4 & 9.4 \\
\hline 2016 & 26.2 & 20.1 & 6.1 & 28.0 & 18.9 & 9.1 \\
\hline 2017 & 23.8 & 18.2 & 5.6 & 28.4 & 19.2 & 9.2 \\
\hline
\end{tabular}


Table 6. Weights of indicators of the second-category countries.

\begin{tabular}{|c|c|c|c|c|c|c|}
\hline Indicator Level & Primary & & Secondary & & Primary & Secondary \\
\hline Indicator & Econ Env & Econ Strength & Econ Stability & $\begin{array}{c}\text { Econ } \\
\text { Openness }\end{array}$ & Legal Env & Legal Factors \\
\hline 2013 & 32.2 & 15.4 & 5.3 & 11.6 & 14.7 & 14.7 \\
\hline 2014 & 34.6 & 17.4 & 5.2 & 11.9 & 13.6 & 13.6 \\
\hline 2015 & 32.9 & 15.9 & 4.5 & 12.6 & 15.2 & 15.2 \\
\hline 2016 & 37.4 & 16.3 & 7.0 & 14.1 & 14.3 & 14.3 \\
\hline 2017 & 32.7 & 15.0 & 4.8 & 12.9 & 13.6 & 13.6 \\
\hline Indicator Level & Primary & \multicolumn{2}{|c|}{ Secondary } & Primary & \multicolumn{2}{|c|}{ Secondary } \\
\hline Indicator & $\begin{array}{c}\text { Political } \\
\text { Env }\end{array}$ & $\begin{array}{c}\text { Gov } \\
\text { Execution }\end{array}$ & $\begin{array}{l}\text { Political } \\
\text { Stability }\end{array}$ & Industry Env & $\begin{array}{l}\text { Comm } \\
\text { Cond. }\end{array}$ & $\begin{array}{l}\text { Logistics } \\
\text { Cond. }\end{array}$ \\
\hline 2013 & 26.1 & 21.5 & 4.6 & 27.1 & 17.7 & 9.4 \\
\hline 2014 & 24.7 & 20.0 & 4.7 & 27.1 & 18.2 & 8.9 \\
\hline 2015 & 25.6 & 20.8 & 4.7 & 26.4 & 17.3 & 9.0 \\
\hline 2016 & 24.4 & 19.5 & 4.9 & 24.0 & 15.1 & 8.8 \\
\hline 2017 & 27.6 & 21.2 & 6.3 & 26.1 & 16.6 & 9.5 \\
\hline
\end{tabular}

From the analysis of the differences between the two types of countries, we find that the industrial environment has more impact on investment climate than the political environment in the first-category countries. Things, however, are the other way around in the second-category countries. To distinguish the characteristics of the cross-border e-commerce investment climate between these two types of countries, the first-category countries are referred to as industry-oriented countries, and the-second category countries as politics-oriented countries and relevant content is shown as follows.

(1) Industry-oriented countries

Countries of this category include Russia, Mongolia and Kazakhstan, whose telecommunication conditions and economic strength have the highest weight, with the government's executive power is in the second place. In practical terms, internet is better developed in these countries, where there is a larger proportion of customer base online and the market is more dynamic.

As a country adjacent to China, Russia has abundant reserves in the economic, military and natural resources. Russia and China have a borderline that stretches as long as $4300 \mathrm{~km}$. Russia has long used its vast territorial span to form a very rich communication culture, and developed a unique communication and e-commerce market. Russia is one of the seven countries in the world with over 100 million Internet users, and its well-developed communication industry and the huge number of Internet users serve a strong basis for the development of the e-commerce market. Since the launch of "the Belt and Road" Initiative, China and Russia have established comprehensive exchange and cooperation mechanisms at various levels such as energy, investment, economy, trade, local and strategic security. At the end of 2016, Russian President Putin proposed to build a digital economy. The Digital Economy Plan was approved in Russia in July 2017 and identified as an important political task in the state of the Union address in March 2018. Better communication and network conditions will greatly facilitate investment and operations of cross-border e-commerce.

Mongolia, a country located to the north of China, boasts unique natural geographical advantage. Mongolia has been connected to the Internet since 1995, and currently, wireless networks, mobile $3 \mathrm{G}$ and $4 \mathrm{G}$ networks have been popularized in the country. Mongolia is complete with a logistics distribution system. The household-based postal plan has been carried out across the country since 2011. The country, therefore, has the conditions for communication services and logistics conditions. In recent years, Mongolia has made great efforts to develop e-commerce by tapping into the "Belt and Road Initiative". E-commerce companies have emerged such as NEW SILKROAD, UBMALL, and APM, which come in various forms including $\mathrm{B} 2 \mathrm{C}$ and $\mathrm{C} 2 \mathrm{C}$, and the products are mainly labor-intensive. Although the development of cross-border e-commerce is still in the initial stage, it has high user vitality and huge market demand. 
Kazakhstan is mainly based on heavy industry, and rather weak in processing industry and light industry. The country is heavily reliant on foreign commodity with most of its domestic consumer goods coming from abroad and it has a huge demand for labor-intensive products. High-tech products, daily necessities, and light industrial products circulating in the market mainly come from the United States, Germany, Japan, Russia, China and other countries. Since the advent of the "Belt and Road Initiative", "digitalization" has been listed by Kazakhstan as one of the five main directions for the country's future development. The government has formulated "Digital Kazakhstan", a national plan for this purpose. From 2013 to 2017, the number of internet users in Kazakhstan soared to 77\% of its population, which puts the country in the 17th place in the world in net user density. The internet users increase steadily in numbers, which offers a great momentum for the future growth.

Thus, the commonality among this type of countries is a great impact on its e-commerce investment climate, a more open economy, a desirable industrial environment and great market potential which may serve key factors in cross-border e-commerce investment.

\section{(2) Politics-oriented countries}

Countries of this type include Ukraine, Belarus and Kyrgyzstan. The index of the government executive power has the highest weight, which plays a more significant role in government accountability, government effectiveness, and government supervision quality.

Ukrainian heavy industry and agriculture are more developed, labor-intensive industries and light industries are underdeveloped, its market has plenty of room for expansion. E-commerce has been advancing rapidly in Ukraine and the number of online customers is rising year by year, making the country the second largest e-commerce market after Russia in Eastern Europe. However, since 2014, as a result of geopolitical influence, Don-bass and Crimea, the war stricken regions, have taken away $20 \%$ of Ukraine's online sales. At the same time, electronic payment system has yet to be legitimized in the country, which to some extent has taken a toll on its e-commerce investment climate. In 2015, Ukraine passed the "On E-commerce" (Act No. 675), which will legally pave the way for trade dispute settlement. At the same time, the country established "the Belt and Road Initiative" Trade and Investment Promotion Center which creates a favorable environment for cross-border e-commerce investors.

Belarus is faced with a grim situation in trade law. Since choices are few in the market, and commodity prices are high, e-commerce has become a new option for Belarusian customers. As Belarus' third largest trading partner and second largest source of imports, China is recognized as one of the friendliest countries to Belarus. The trade between the two countries is complementary. Belarus and China have maintained a good cooperative relationship by establishing the "China-Belarus Industrial Park". Since the launch of "the Belt and Road Initiative", Belarus has phased in new policies and laws and formulated new e-commerce regulations to secure e-commerce development. In June 2020, China and Belarus reached consensus on continuing to deepen cooperation in building the "Belt and Road". However, in recent times, there have been manifestations in Belarus for political reasons and the protests have become increasingly radical. At the same time, the Belarusian government has demanded restrictions on Internet during the protests. This further confirms our findings that the political environment is unstable and that discretion is needed when making investments.

Kyrgyzstan has a weak industrial base, and is predominantly dependent on agriculture and animal husbandry. Though it is underdeveloped in economy, Kyrgyzstan is a coveted spot for foreign investors, thanks to its unique geographical location, free trade port and processing zone. However, the country is faced with multiple difficulties given the fact that it has no complete and convenient telecommunication network, a government-led plan, and it has undergone a significant amount of political turmoil.

The commonality of investment in this type of countries is that there is great market potential but the political environment is unstable. Investors need remain cautious. 
In general, industry-oriented countries generally outweigh politics-oriented countries in term of cross-border e-commerce investment climates. It is our recommendation that investors give priority to industry development and freedom instead of relying heavily on regulation.

Based on the results of the neural network with genetic algorithm, we can draw the following conclusions.

(1) From a macro perspective, we do not find a single positive correlation between the final score and the purely quantitative indicators such as total GDP, per capita GDP, railway mileage, aviation mileage, etc., which indicates that there is not a strong link between the comprehensive score of the market investment climate and the absolute quantity of indicators and the entropy evaluation method is objectivity.

(2) From the perspective of economic environment, these 10 sets of data reveal that the total GDP value fluctuates within the range from several hundred to tens of thousands, but there is correlation between the corresponding GDP growth rate and the annual inflation. If the total economic volume is huge and its GDP is growing steadily with a high per capita GDP and corresponding rise in inflation rate, the score will be high, as shown in the 2th and 8th sets of data. This shows that the country's economic development is stable with a high economic level, people have strong consumption power, which is a good opportunity for cross-border e-commerce investors. Seen from the 1st and 5th sets of data, its GDP growth rate is lower than the inflation rate, and it has a relatively high score in legal environment, which indicates that, despite its low economic growth rate, the sound legal environment can help improve and optimize the investment climate, enhance the impact, which suggests that the country is worth considering an investment destination. In addition, it can be found from the 3rd, 4th and 6th sets of data that the GDP growth rate is negative, and the inflation rate is more obvious than the negative growth rate of GDP growth rate. Therefore, it can be inferred that such countries may have problems such as overall social production overcapacity, government tightening budgets, decline in aggregate social demand, lower investment and consumption expectations, and higher exchange rates. When deflation reaches its limit, the economy will gradually recover under the stimulation of demand. Therefore, investors can invest at the right time.

(3) From the perspective of the political environment and the legal environment, four three-level evaluation indicators of the political environment complement each other. It can be seen from the 1st, 2nd, 3rd, 6th, 8 th, and 10th sets of data that at least one of the four indicators are above $80 \%$, which can reflect the great impact of the political environment in a certain direction. Political stability, good quality of supervision, high government accountability and government efficiency are the prerequisites for a sound e-commerce market environment. The legal environment scores for groups 4 and 5 are higher than $85 \%$, indicating that a good legal environment has greater benefits for e-commerce investment.

(4) From the perspective of the industry environment, it can be seen from the 2nd, 3rd, 6th, 7th, 9th and 10th sets of data that a relatively large number of secure internet servers can serve a good channel for e-commerce and promote convenience in online shopping. The rest sets of data do not show a decided advantage in the number of secure internet servers and internet penetration rate, but the high passenger volume in railway and airline transport, and convenient logistics add weight to cross-border e-commerce investment climate.

(5) A comprehensive analysis of the four major types of environment reveals that a large number in the combined volume of both railway and airline passenger tends to generate high comprehensive scores, from which we can infer that logistics infrastructure is the most fundamental factor in cross-border e-commerce investment. After the requirement for the logistics conditions is met, it can be seen from a comparative analysis of groups 5, 6 and group 9 that a country may have a poor economic environment and deflation, but it can attain a higher score provided that either government or legal environment is given prominence. In a time of 
economic austerity, politically-oriented countries with better logistics conditions can also serve investment destinations.

\section{Conclusions}

Conclusions can be drawn as below after evaluating and analyzing the cross-border e-commerce investment climate of the countries along "the Belt and Road Initiative". First, of the seven countries, Russia has the best cross-border e-commerce investment climate, followed by Kazakhstan and Mongolia. Tajikistan has the worst investment climate.

Second, in all of the seven countries, the economic environment has the greatest impact on the e-commerce investment climate, the legal environment has the weakest impact, and the industrial environment and political environment have a moderate impact on the e-commerce investment climate. Investors should give priority to the national economic situation when selecting an investment destination among the seven countries. The better the economic environment, the more conducive to e-commerce investment.

Third, seven countries are classified by comprehensive score. For the first type of industry-led countries, namely, Russia, Mongolia and Kazakhstan, the national industrial environment has a greater impact than the political environment. They are more conducive to e-commerce investment. Such countries have higher openness and network communication level, the development of the network platform is relatively good. They have the industry environment for e-commerce. For the second type of politically-oriented countries, including Ukraine, Belarus and Kyrgyzstan, they have relatively more prominent political influences. Such countries are relatively weak in openness, more inclined to the government, and have poor communication and network foundations. Additionally, some countries have political and territorial disputes, which increase the risk in investment. Ukraine is typical of this type. Cross-border e-commerce investors need remain cautious in choosing the destination country.

Fourth, we use a neural network in combination with genetic algorithm to optimize the established index evaluation system and make it applicable to other countries. It can be seen from the results that the indicators interact and correlate each other, which reflects the objectivity of the entropy method. In assessment of the investment climate in each country, the following characteristics of indicators and their relevance can be used for selection and judgment. In terms of economic environment, if the country has stable economic growth and high inflation rate, the overall score tends to be relatively high and the investment risk is relatively low. If economic growth is slow and deflation occurs, timely investment can be made in conjunction with legal environment. Investment is an option if a country shows obvious advantage in any one of the following three areas, namely, political stability, government enforcement, or legal environment. For investors, a country is worth considering if it is competitive in either logistics or communication conditions. Politically-oriented countries, despite their poor economy and deflation, still merit consideration provided that their logistics conditions are desirable.

Investment climate for China's cross-border e-commerce is studied in this paper. An evaluation system is established and seven "the Belt and Road Initiative" land countries are analyzed including Russian Federation, Mongolia, Ukraine, Kazakhstan, Tajikistan, Kyrgyzstan and Belarus. The importance of indicators that affect the investment climate is researched, and the weight of each indicator is obtained. Prior to this, there has been no relevant research to establish an indicator system for cross-border e-commerce. This is an innovation of the paper. To verify the objectivity of the model and make it applicable to the evaluation of many other countries, the back propagation neural network method is used to map the existing index data and the genetic algorithm is used to optimize the evaluation index system, which is new in this field. In the current trend of trade globalization and booming e-commerce, the research can help cross-border e-commerce companies to make effective investments and improve the quality and efficiency of trade cooperation between countries.

Some limitations of this study should be addressed in the future. First, in the research, the number of samples is limited, and only seven representative countries are selected. There are many people 
around the world that order products from China via the Internet, so the analysis of seven countries may not be enough. Secondly, the study was not conducted by industry, and the investment climate evaluation indicators may be different in different industries. Therefore, there are some future research directions available. Researchers can choose more countries to study the investment climate of cross-border e-commerce, which can be explored by continent, or can be discussed based on the use of e-commerce by people in different countries. At the same time, the study can be conducted by industry category. For example, electronics and apparel may have different needs for the industry environment. Moreover, different countries have different customs and cultures, factors such as the cultural environment of investee countries can be taken into account in the evaluation index system.

Author Contributions: Conceptualization, Y.L. and X.Q.; methodology, Y.L. and X.Q.; software, Y.L. and X.Q.; formal analysis, Y.L.; data curation, Y.L.; writing — original draft preparation, Y.L. and X.Q.; writing-review and editing, Y.L. and X.Q.; All authors have read and agreed to the published version of the manuscript.

Funding: This research was funded by The National Social Science Fund of China, grant number 15AGL002.

Conflicts of Interest: The authors declare no conflict of interest.

\section{References}

1. Chen, S.C.; Hou, J.; Xiao, D. “One Belt, One Road” Initiative to stimulate trade in China: A counter-factual analysis. Sustainability 2018, 10, 3242. [CrossRef]

2. Huang, Y. Understanding China's Belt \& Road Initiative: Motivation, framework and assessment. China Econ. Rev. 2016, 40, 314-321.

3. Michawl, D.; Liu, W.D. Chinese perspectives on the belt and road initiative. Camb. J. Reg. Econ. Soc. 2019, 12, 145-167.

4. Kamel, M.S. China's Belt and Road Initiative: Implications for the Middle East. Camb. Rev. Int. Aff. 2018, 31, 76-95. [CrossRef]

5. Herrero, A.G.; Xu, J.W. China's belt and road initiative: Can Europe expect trade gains. China World Econ. 2017, 25, 84-99. [CrossRef]

6. Huang, R.; Nie, T.; Zhu, Y.; Du, S. Forecasting trade potential between China and the five central Asian countries: Under the background of belt and road initiative. Comput. Econ. 2020, 55, 1233-1247. [CrossRef]

7. Ministry of Commerce of the People's Republic of China. Available online: http://www.mofcom.gov.cn/ article/i/jyjl/e/202007/20200702986468.shtml (accessed on 27 July 2020).

8. Yin, M.; Ruangkanjanases, A.; Chen, S.C. Investigating the impact of critical factors on continuance intention towards cross-border shopping websites. Sustainability 2019, 11, 5914.

9. Belt and Road Portal-YIDAIYILU.GOV.CN. Available online: https://www.yidaiyilu.gov.cn/xwzx/gnxw/ 122663.htm (accessed on 13 April 2020).

10. Central People's Government of the People's Republic of China. Available online: http://www.gov.cn/ xinwen/2019-11/15/content_5452490.htm (accessed on 15 November 2019).

11. Buckley, P.J.; Clegg, L.J.; Cross, A.R.; Liu, X.; Voss, H.; Zheng, P. The determinants of Chinese outward foreign direct investment. J. Int. Bus. Stud. 2007, 38, 499-518. [CrossRef]

12. Ministry of Commerce of the People's Republic of China. Available online: http://file.mofcom.gov.cn/article/ gkml/201805/20180502740111.shtml (accessed on 7 May 2018).

13. Belt and Road Portal-YIDAIYILU.GOV.CN. Available online: https://www.yidaiyilu.gov.cn/zchj/rcjd/60645. htm (accessed on 20 July 2018).

14. Pan, H.; Zhou, H.X. Study on convolutional neural network and its application in data mining and sales forecasting for e-commerce. Electron. Commer. Res. 2020, 20, 297-320. [CrossRef]

15. Li, G.; Li, N. Customs classification for cross-border e-commerce based on text-image adaptive convolutional neural network. Electron. Commer. Res. 2019, 19, 779-800. [CrossRef]

16. Zhou, L.C. Product advertising recommendation in e-commerce based on deep learning and distributed expression. Electron. Commer. Res. 2020, 20, 321-342. [CrossRef]

17. Liébana-Cabanillas, F.; Marinkovic, V.; Kalinic, Z. A SEM-neural network approach for predicting antecedents of m-commerce acceptance. Int. J. Inf. Manag. 2017, 37, 14-24. [CrossRef] 
18. Leong, L.Y.; Hew, T.S.; Ooi, K.B.; Tan, G. Predicting actual spending in online group buying-An artificial neural network approach. Electron. Commer. Res. Appl. 2019, 38, 100898. [CrossRef]

19. Vincent, O.R.; Makinde, A.S.; Akinwale, A.T. A cognitive buying decision-making process in B2B e-commerce using Analytic-MLP. Electron. Commer. Res. Appl. 2017, 25, 59-69. [CrossRef]

20. Taneja, A.; Arora, A. Modeling user preferences using neural networks and tensor factorization model. Int. J. Inf. Manage. 2019, 45, 132-148. [CrossRef]

21. Lee, H.C.; Rim, H.C.; Lee, D.G. Learning to rank products based on online product reviews using a hierarchical deep neural network. Electron. Commer. Res. Appl. 2019, 36, 100874. [CrossRef]

22. Gil-Cordero, E.; Cabrera-Sánchez, J.-P. Private label and macroeconomic indexes: An artificial neural networks application. Appl. Sci. 2020, 10, 6043. [CrossRef]

23. Farhadi, M.; Abbaspour-Gilandeh, Y.; Mahmoudi, A.; Maja, J.M. An integrated system of artificial intelligence and signal processing techniques for the sorting and grading of nuts. Appl. Sci. 2020, 10, 3315. [CrossRef]

24. Adães, J.; Pires, J.C.M. Analysis and modelling of PM2.5 temporal and spatial behaviors in European cities. Sustainability 2019, 11, 6019. [CrossRef]

25. Sharma, S.K.; Chakraborti, S.; Jha, T. Analysis of book sales prediction at Amazon marketplace in India: A machine learning approach. Inf. Syst. E-Bus. Manag. 2019, 17, 261-284. [CrossRef]

26. Wang, G. The Belt and Road Initiative in quest for a dispute resolution mechanism. Asia Pac. Law Rev. 2017, 25, 1-16. [CrossRef]

27. Wu, T.B.; Zhang, B.; Cao, Y.K.; Sun, P.J. Impact of Multi-Dimensional and Dynamic Distance on China's Exports of Wooden Forest Products to Countries along the "Belt and Road". Sustainability 2020, 12, 3339. [CrossRef]

28. Song, C.Q.; Ge, Y.J.; Liu, Y.G.; Zhou, S.Y.; Wu, X.L.; Hu, Z.D.; Cheng, C.X.; Gao, J.B.; Fang, C.L.; Han, Z.L.; et al. Undertaking research on Belt and Road Initiative from the geo-relation perspective. Geogr. Res. 2018, 37, 3-19.

29. Jean-Marc, F.B.; Colin, F. The Geopolitics of China's Maritime Silk Road Initiative. Geopolitics 2017, $223-245$.

30. Lee, T.W.; Hu, Z.H.; Lee, S.J.; Dyoung-Suk, C. Research trends and agenda on the Belt and Road (B\&R) initiative with a focus on maritime transport. Marit. Policy Manag. 2018, 45, 282-300.

31. Julien, C. China's International Investment Strategy-Bilateral, Regional, and Global Law and Policy International Economic Law Series; Oxford University Press: London, UK, 2019; p. 576.

32. Liu, W.D.; Michael, D.; Gao, B.Y. A discursive construction of the Belt and Road Initiative: From neo-liberal to inclusive globalization. J. Geo. Gr. Sci. 2018, 28, 1199-1214. [CrossRef]

33. Ailan, L.; Lu, C.C.; Wang, Z.X. The roles of cultural and institutional distance in international trade: Evidence from China's trade with the Belt and Road countries. China Econ. Rev. 2020, 61, 101234.

34. Litvak, I.A.; Banting, P.M. A Conceptual Framework for International Business Arrangement. Marketing and the New Science of Planning; American Marketing Association: Chicago, IL, USA, 1968; pp. 460-467.

35. Yang, L.C. An evaluation of the investment environment in international logistics zones: A Taiwanese manufacturer's perspective. Int. J. Prod. Econ. 2007, 107, 279-300.

36. Maung, M.; Shedden, M.; Wang, Y.; Wilson, C. The investment environment and cross-border merger and acquisition premiums. J. Int. Financ. Mark. Inst. Money 2018, 59, 19-35. [CrossRef]

37. Ershova, N. Investment climate in Russia and challenges for foreign business: The case of Japanese companies. J. Eurasian Stud. 2017, 8, 151-160. [CrossRef]

38. Beleska-Spasova, E.; Loykulnanta, S.; Nguyen, Q.T.K. Firm-specific, national and regional competitive advantages: The case of emerging market MNEs-Thailand. Asian. Bus. Manag. 2016, 15, $264-291$. [CrossRef]

39. Bevan, A.A.; Estrin, S. The determinants of foreign direct investment into European transition economies. J. Comp. Econ. 2004, 32, 775-787. [CrossRef]

40. Bruneckiene, J.; Jucevicius, R.; Zykiene, I.; Rapsikevicius, J.; Lukauskas, M. Assessment of investment attractiveness in European countries by artificial neural networks: What competences are needed to make a decision on collective well-being? Sustainability 2019, 11, 6892. [CrossRef]

41. Peng, H.G.; Shen, K.W.; He, S.S.; Zhang, H.Y.; Wang, J.Q. Investment risk evaluation for new energy resources: An integrated decision support model based on regret theory and ELECTRE III. Energy Conv. Manag. 2019, 183, 332-348. [CrossRef] 
42. Zhou, N.; Wu, Q.; Hu, X.; Xu, D.; Wang, X. Evaluation of Chinese natural gas investment along the Belt and Road Initiative using super slacks-based measurement of efficiency method. Resour. Policy 2020, 67, 101668. [CrossRef]

43. Joaquín, J.J. Determinants of country competitiveness in attracting mining investments: An empirical analysis. Resour. Policy 2017, 52, 65-71.

44. Deng, S.; Li, Y.; Chen, J. Evaluating foreign investment environment in China: A systematic approach. Eur. J. Oper. Res. 1997, 100, 16-26. [CrossRef]

45. Nam, D.I.; Kim, J.; Arthurs, J.D.; Sosik, J.J.; Cullen, J.B. Measurement and structural invariance of entrepreneurial investment climate: A cross-country scale development. Int. Bus. Rev. 2016, 25, 1053-1065. [CrossRef]

46. Veganzones-Varoudakis, M.A.; Nguyen, H.T.M. Investment climate, outward orientation and manufacturing firm productivity: New empirical evidence. Appl. Econ. 2018, 50, 5766-5794. [CrossRef]

47. Guo, X.G. Improved entropy method and its application in economic benefit evaluation. Syst. Eng. Theory Pract. 1998, 18, 98-102.

48. Luan, W.; Lu, L.; Li, X.; Ma, C. Weight determination of sustainable development indicators using a global sensitivity analysis method. Sustainability 2017, 9, 303. [CrossRef]

49. Hua, S.; Ling, B. The Fuzzy Integrative Evaluation Model and Empirical Study of Enterprise Strategy Risk Based on AHP-Entropy Combination Weight Method. In Proceedings of the 2010 International Conference on Management Science \& Engineering 17th Annual Conference, Melbourne, Australia, 24-26 November 2010; pp. 334-341.

Publisher's Note: MDPI stays neutral with regard to jurisdictional claims in published maps and institutional affiliations. 